\title{
Production of 1, 3 regiospecific lipase from Bacillus sp. RK-3: Its potential to synthesize Cocoa Butter Substitute
}

\author{
R. K. Saxena ${ }^{1 \star}$, Swati Misra ${ }^{1}$, Isha Rawat ${ }^{1}$, Pritesh Gupta $^{1}$, Kakoli Dutt $^{1}$ and V. S. Parmar ${ }^{2}$ \\ ${ }^{1}$ Department of Microbiology, University of Delhi South Campus, Benito Juarez Road, New Delhi -110021, India. \\ ${ }^{2}$ Department of Chemistry, University of Delhi, Delhi -110007, India. \\ E-mail: rksmicro@yahoo.co.in; rksmicro@hotmail.com
}

Received 30 April 2010; received in revised form 3 July 2010; accepted 12 July 2010

\begin{abstract}
A Bacillus sp. RK-3 isolated from soil initially produced $3.28 \mathrm{IU} / \mathrm{mL}$ of 1,3 regiospecific lipase in medium containing $1.0 \%$ olive oil. After process optimization, $10.56 \mathrm{IU} / \mathrm{mL}$ of lipase was produced in medium containing sunflower oil $1.5 \%$, tryptone $2 \%, \mathrm{Ca}^{2+} 20 \mathrm{mM}$ using $3 \%$ inoculum in $250 \mathrm{~mL}$ Erlenmeyer flask containing $50 \mathrm{~mL}$ of the medium at $\mathrm{pH} 7.0$, $250 \mathrm{rpm}$ and $30^{\circ} \mathrm{C}$ for $36 \mathrm{~h}$. Scale up in $10 \mathrm{~L}$ bioreactor with $7.5 \mathrm{~L}$ of the optimized medium yielded $16.41 \mathrm{IU} / \mathrm{mL}$ in $30 \mathrm{~h}$ resulting in net 6.0 fold increase in enzyme units as against initial units of $3.28 \mathrm{IU} / \mathrm{mL}$ obtained under unoptimized conditions. The productivity in $10 \mathrm{~L}$ bioreactor is $0.547 \mathrm{IU} / \mathrm{mL} / \mathrm{h}$ as against initial of $0.091 \mathrm{IU} / \mathrm{mL} / \mathrm{h}$. The lipase exhibited $95.12 \%$ stability in hexane, followed by THF $(75.83 \%)$ and petroleum ether $(73.85 \%)$ after $24 \mathrm{~h}$ of incubation. Cocoa butter substitute (CBS) synthesis was attempted in a reaction containing $1.2 \mathrm{IU} / \mathrm{mg}$ of lipase using palm oil and methyl stearate in hexane. The reaction product being formed was analyzed qualitatively using Thin Layer Chromatography (TLC) and quantified by gas chromatography (GC) which showed 83.17\% conversion efficiency for CBS in $24 \mathrm{~h}$.
\end{abstract}

Keywords: lipase, production, Bacillus RK-3, cocoa butter substitute

\section{INTRODUCTION}

Lipase (triacylglycerol acyl hydrolase E.C. 3.1.1.3) catalyzes the hydrolysis and synthesis of long chain acylglycerols under aqueous, microaqueous and in organic solvents (Jaeger et al., 1999; Saxena et al., 1999; Hasan et al., 2006). This enables lipase to carry out a variety of different catalytic reactions like hydrolysis, esterification, transesterification, alcoholysis, acidolysis and ammonolysis which are important and are exploited in industries such as food and feed, detergents, pharmaceutical, leather, textile and paper (Saxena et al., 1999; Hasan et al., 2006). Though lipases are obtained from animal and plant sources too, the microbial lipases are of immense importance due to their regiospecific and fatty acid specificity. These properties are exploited for the retailoring of cheap vegetable oils to produce nutritionally important structured triacylglycerols like polyunsaturated fatty acids (PUFA), cocoa butter substitutes (CBS) etc (Sharma et al., 2001; Hasan et al., 2006).

Cocoa butter (CB) is used in confectionaries and cosmetics due to its flavour and aroma. It is characterized by sharp melting point, desirable physicochemical properties and fatty acid components (Shukla, 1996; Smith, 2001; Tchobo et al., 2009). The major components of CB are saturated-unsaturated-saturated (SUS) triacylglycerols which make it hard and brittle at room temperature but allow it to melt completely in the mouth (Lipp and Anklam, 1998; Wang et al., 2006; Liu et al., 2007). When used in a product, CB gives it a smooth texture, contractibility, flavour release and gloss (Liu et al., 2007).

However, due to the new directives of the European Union on chocolate along with the limited supply of $C B$, variability in quality, large demand and volatility in prices has made the search for alternatives a necessity (Tchobo et al., 2009). Several researchers report the use of 1,3 regiospecific lipases to transesterify lower value fats and oils to synthesize CBS (Macrae and Hammond, 1985; Adlercrutz, 1994; Abigor et al., 2003. Though, lipases from plants like Carica papaya have been reported for CBS synthesis (Pinyaphong and Phutrakul, 2009), however, microbial lipases are preferred for enzyme mediated reactions due to the ease in their availability and production. 1, 3 regiospecific lipases have been reported from many fungi like Aspergillus, Rhizopus, Candida etc and bacteria like Pseudomonas and Bacillus (Saxena et al., 1999; Sharma et al., 2001).

Here, we report the production of a 1, 3 regiospecific lipase from newly isolated Bacillus sp. RK-3, its process optimization and scale up to a $10 \mathrm{~L}$ bioreactor. The lipase produced was partially purified and lyophilized. The dried enzyme was now used for synthesis of CBS.

\section{MATERIALS AND METHODS}

\section{Chemicals and reagents}

$p$-Nitro phenyl palmitate ( $p$-NPP), methyl stearate, monolein, diolein, oleic acid were purchased from Sigma 
chemicals (St. Louis, USA) and silica gel $60 \mathrm{~F}_{254}$ plates from Merck, Germany. Cocoa butter and palm oil were obtained from the local market. All other medium components and chemicals used were of analytical grade and were purchased locally (Himedia, Qualigenes and Sisco Research Laboratories Ltd., India).

\section{Microorganism}

A lipase producing bacterium Bacillus sp. RK-3, isolated from soil grows optimally at $37^{\circ} \mathrm{C}$ and $\mathrm{pH} 7.0$ in nutrient broth. This organism was maintained on nutrient agar slants containing $1 \%$ sunflower oil in a BOD incubator at $10{ }^{\circ} \mathrm{C}$ (Yorco Sales Pvt. Ltd., New Delhi) with periodic sub-culturing.

\section{Enzyme production}

Lipase production was carried out in medium $(50 \mathrm{~mL}$ in $250 \mathrm{~mL}$ Erlenmeyer flasks) containing ( $\mathrm{g} / \mathrm{L})$ : olive oil 1.0, glucose 2.0, peptone 5.0, beef extract 5.0, $\mathrm{Na}_{2} \mathrm{SO}_{4} 2.0$, $\mathrm{KH}_{2} \mathrm{PO}_{4} 1.0, \mathrm{~K}_{2} \mathrm{HPO}_{4} 3.0, \mathrm{MgSO}_{4} \cdot 7 \mathrm{H}_{2} \mathrm{O}$ 0.1, pH 7.0. Gum acacia $(1.0 \%)$ was used as an emulsifier. Inoculum raised in nutrient broth (cell density at $600 \mathrm{~nm}=0.6-0.8$ ) was used at $2 \%(\mathrm{v} / \mathrm{v})$ concentration. Incubation was carried out at $37{ }^{\circ} \mathrm{C}$ and $200 \mathrm{rpm}$ with regular sampling at $12 \mathrm{~h}$ intervals till $48 \mathrm{~h}$. The samples were centrifuged at 8,000 rpm for $15 \mathrm{~min}$ at $4{ }^{\circ} \mathrm{C}$. The cell free supernatant was used as lipase source.

\section{Lipase assay procedure}

The lipase assay procedure of Winkler and Stuckmann, (1979) was used. To $2.4 \mathrm{~mL}$ of freshly prepared $p$-NPP solution $(30 \mathrm{mg}$ of $p$-NPP was dissolved in $10 \mathrm{~mL}$ of isopropanol and mixed with $90 \mathrm{~mL}$ of Sorenson buffer, $\mathrm{pH}$ 9.0), $0.1 \mathrm{~mL}$ of culture filtrate was added. The reaction mixture was incubated at $37 \pm 1^{\circ} \mathrm{C}$ in a water bath shaker for $30 \mathrm{~min}$. The reaction was terminated by the addition of $0.1 \mathrm{~mL}$ of $300 \mathrm{mM} \mathrm{CaCl}_{2}$ (fused) solution. The reaction mixture was then centrifuged to clarify the solution. The absorbance of the supernatant was read at $410 \mathrm{~nm}$ (Shimadzu UV1700 Pharma Spec). Lipase activity was calculated from standard curve of $p$-nitro phenol prepared in the range of $10-100 \mu \mathrm{g} / \mathrm{mL}$.

The international unit (IU) of lipase activity by $p$-NPP method is defined as the amount of enzyme required to release of $1.0 \mu$ mole of free phenol from the substrate per $\mathrm{mL}$ per min under the standard assay conditions.

\section{Evaluation of lipase for 1, 3 regiospecificity}

Regiospecificity of the nature of the lipase produced from this Bacillus sp. RK-3 was confirmed by the triglyceride hydrolysis. For this, $1.0 \mathrm{~mL}$ of triolein was incubated with $5.0 \mathrm{~mL}$ of enzyme sample at $30^{\circ} \mathrm{C} ; 100 \mathrm{rpm}$ for $24 \mathrm{~h}$. Aliquots of $200 \mathrm{LI}$ were withdrawn after $24 \mathrm{~h}$ and mixed with $5.0 \mathrm{~mL}$ of diethyl ether to terminate the reaction. The hydrolyzed products formed were analyzed on Thin Layer
Chromatography (TLC) plates (Silica gel 60F, Merck, Germany) using a solvent system comprising of petroleum ether, diethyl ether and acetic acid in the ratio of 80:30:1. Spots were visualized by incubating the TLC plates in a saturated iodine chamber. The 1,3 regiospecific lipase of Rhizomucor miehei obtained from Sigma (St.Louis, USA) was used as control.

\section{Process optimization for lipase production}

Different lipid sources (olive, sunflower, coconut, corn, mustard, linseed, groundnut, castor and soybean oils) were evaluated for lipase production at $1.0 \%$ concentration. The concentration of the optimal lipid source was further optimized between 0.5 to $3.0 \% \mathrm{v} / \mathrm{v}$. Other physiological parameters like temperature (25-50 $\left.{ }^{\circ} \mathrm{C}\right)$, agitation rate $(100-300 \mathrm{rpm})$ and $\mathrm{pH}(4.0-11.0)$ were also examined for their effect on lipase production. Effect of different organic and inorganic nitrogen sources $(1.0 \%$ $\mathrm{w} / \mathrm{v})$ such as peptone, beef extract, yeast extract, tryptone, casein hydrolysate, urea, ammonium chloride, ammonium nitrate, diammonium dihydrogen phosphate and sodium nitrate were evaluated for lipase production. The effect of different carbon sources (fructose, lactose, sucrose, maltose, mannitol, sorbitol and glycerol) at $0.2 \%$ $\mathrm{w} / \mathrm{v}$ was investigated for lipase production. Various surfactants $(0.02 \%)$ and metal ions $\left(\mathrm{NH}_{4}^{+}, \mathrm{Ba}^{2+} \mathrm{Fe}^{3+}\right.$, $\mathrm{Mg}^{2+}, \mathrm{Mn}^{2+}, \mathrm{K}^{+}, \mathrm{Cu}^{2+}$ and $\mathrm{Ca}^{2+}$ ) at a concentration of 20 $\mathrm{mM}$ were evaluated for lipase production. Inoculum concentration (cell density at $600 \mathrm{~nm}=0.6-0.8$ ) was optimized in the range $1-5 \%(v / v)$.

\section{Scale up of lipase production}

Large scale production of lipase was carried out in a $10 \mathrm{~L}$ bioreactor (Bioflo IV, New Brunswick Scientific Inc., USA) containing $7.5 \mathrm{~L}$ working volume of the optimized production medium. Sterilization was carried out at $121^{\circ} \mathrm{C}$ for $15 \mathrm{~min}$ in situ. Fermentation was carried out at $30 \pm 1$ ${ }^{\circ} \mathrm{C}, 3.0 \%$ inoculum, aeration of $4.0 \mathrm{vvm}$ and $250 \mathrm{rpm}$. Foaming was controlled by adding sterilized silicon oil during fermentation. The $\mathrm{pH}$ was maintained by the addition of $1 \mathrm{~N} \mathrm{NaOH} / 1 \mathrm{~N} \mathrm{HCl}$ during fermentation. The dissolved Oxygen (DO) levels were maintained at 20-40 $\%$ saturation by agitation-aeration cascade system. Samples were withdrawn every six hours till $48 \mathrm{~h}$ and were estimated for lipase activity.

\section{Partial Purification}

The cell free supernatant containing lipase was precipitated overnight using ammonium sulphate at $80 \%$ saturation at $4{ }^{\circ} \mathrm{C}$. The precipitate obtained after centrifugation was dissolved in $0.05 \mathrm{M}$ glycine $\mathrm{NaOH}$ buffer ( $\mathrm{pH}$ 9.0) and dialyzed against the same buffer with 3-4 changes every $4 \mathrm{~h}$. The lipase rich dialysate was lyophilized (Vertis Genesis, 35 EL). This partially purified concentrated lyophilized lipase sample was examined for its stability in various solvents and was further evaluated for CBS synthesis. 


\section{Effect of organic solvents on lipase activity and stability}

Partially purified and lyophilized lipase $(10 \mathrm{mg})$ was incubated with $1 \mathrm{~mL}$ of different organic solvents (benzene, methanol, chloroform, hexane, petroleum ether and propanol) at $37^{\circ} \mathrm{C}, 250 \mathrm{rpm}$ for $24 \mathrm{~h}$ in screw- tight vials. The samples were centrifuged and the organic solvents were decanted and evaporated at room temperature. Dried samples thus obtained were then dissolved in $1 \mathrm{~mL}$ of glycine- $\mathrm{NaOH}$ buffer $(0.05 \mathrm{M}, \mathrm{pH} 9.0)$ and the residual lipase activity was determined. The activity of enzyme was also assayed in buffer in the absence of the organic solvent which served as control.

All experiments were run in triplicate sets and the mean values are presented. The values were analyzed by Student's t-test.

\section{Synthesis of cocoa butter substitute}

Palm oil $(5.0 \mathrm{~mL})$ was mixed with $4.0 \mathrm{~g}$ of methyl stearate in presence of $50 \mathrm{~mL}$ hexane. To this, $100 \mathrm{mg}$ of partially purified lyophilized lipase and molecular sieves were added. The reaction mixture was incubated overnight at $37{ }^{\circ} \mathrm{C}$. After incubation, contents were filtered by Whatman filter paper (No.1) and solvent was evaporated. The filtrate thus obtained was analyzed for cocoa butter substitute synthesis on TLC and subsequently by GC and Nuclear Magnetic Resonance (NMR) analysis.

The solvent system used for TLC analysis was hexane: diethyl ether (4:1). The standards of palm oil, methyl stearate and cocoa butter were compared with that of CBS synthesized by transesterification reaction by this lipase. Various concentrations of CBS formed were analyzed on GC. The analysis of standard cocoa butter substitute, control (without lipase) and sample (with reaction) was performed on a Shimadzu instrument using an RT TM-2330 column with split injection and FID detection. The injection temperature and the detector temperature was $250{ }^{\circ} \mathrm{C}$. A gas flow of $10 \mathrm{cc} / \mathrm{min}(\mathrm{H})$ and a split ratio of $45: 1 \mathrm{~mL} / \mathrm{min}$ were applied. The temperature programme of the oven was: $200{ }^{\circ} \mathrm{C}$ to $250{ }^{\circ} \mathrm{C} @ 8$ ${ }^{\circ} \mathrm{C} / \mathrm{min}$ (hold $3 \mathrm{~min}$ ). One micro liter of sample was injected with a $10 \mu \mathrm{L}$ glass syringe (Hamilton). ${ }^{1} \mathrm{H}$ NMR was carried out using JEOL 400,400 MHz.

\section{RESULTS AND DISCUSSION}

A newly isolated bacterium identified as Bacillus sp. RK-3 produces $3.28 \mathrm{IU} / \mathrm{mL}$ of lipase under initial unoptimized conditions in $36 \mathrm{~h}$. Process optimization of lipase production from this organism was carried out to increase lipase yield to effectively reduce the quantity used per reaction. The increased yield will improve the process economics for the different lipase catalyzed/mediated reactions including synthesis of cocoa butter substitute.

\section{Process optimization of lipase production}

Since lipid sources significantly influence lipase production, various lipidic sources were evaluated. The data presented shows an increase in lipase titres when sunflower oil $(3.68 \mathrm{IU} / \mathrm{mL})$ was used instead of olive oil (3.28 IU $/ \mathrm{mL})$ which was the control. A similar preference for sunflower oil has been reported by Kulkarni and Gadre (2002) for Pseudomonas fluorescens lipase. On the other hand, olive oil is the preferred lipid source for Bacillus mycoides and B. multivorans (Thomas et al., 2003; Gupta et al., 2007).

When the temperature was lowered from $37^{\circ} \mathrm{C}$ to 30 ${ }^{\circ} \mathrm{C}$, nearly 1.6 fold increase in lipase yield to $5.16 \mathrm{IU} / \mathrm{mL}$ was recorded. Similarly, a lower optimal temperature of 30 ${ }^{\circ} \mathrm{C}$ was reported for lipase production from Streptomyces rimosus (Abramic et al., 1999), P. aeruginosa LST-03 (Rathi et al., 2002) and P. fluorescens NS2W (Kulkarni and Gadre, 2002). However, on the contrary, a much higher temperature of $45^{\circ} \mathrm{C}$ has been reported by Rathi et al. (2002) from Burkholderia cepacia. Optimal lipase production from this organism was at $\mathrm{pH} 7.0$ which is also the control. Similar was reported for lipase production from Bacillus sp. (Sugihara et al., 1991) and Acinetobacter radioresistens (Li et al., 2001).

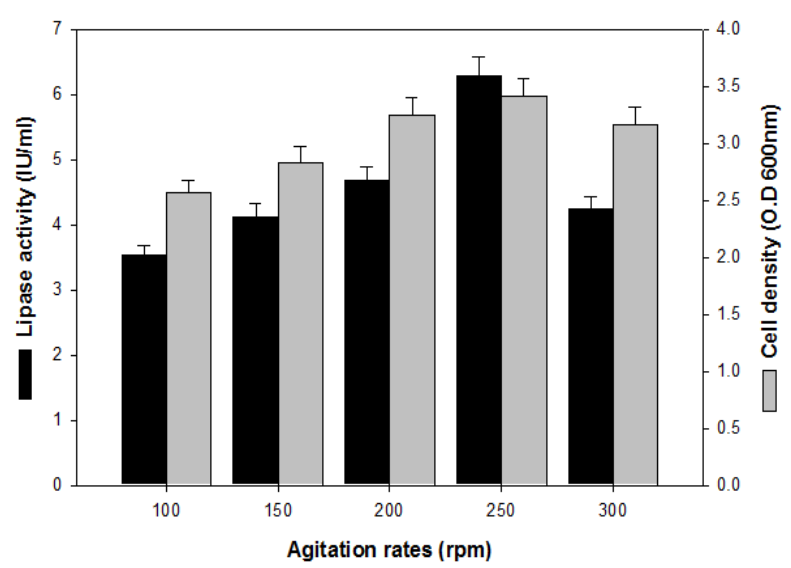

Figure 1: Effect of different agitation rates on lipase production by Bacillus sp. RK-3 in medium containing $1.5 \%$ sunflower oil $(\mathrm{v} / \mathrm{v})$

Here, lipase production increased to $6.28 \mathrm{IU} / \mathrm{mL}$ when the agitation rate was increased to $250 \mathrm{rpm}$ (Figure 1). This increase in lipase titers may be attributed to an increase in oxygen transfer rate to the organism for growth and lipase production (Lawrence et al., 1967). However, lower agitation rates of $150 \mathrm{rpm}$ for Pseudomonas sp. (Gao et al., 2000), $160 \mathrm{rpm}$ for $P$. luteola (Litthauer et al., 2002) and $200 \mathrm{rpm}$ for $P$. fluorescens NS2W (Kulkarni and Gadre, 2002) has been reported while $250 \mathrm{rpm}$ enhanced lipase production from Pseudomonas aeruginosa LST-03 (Ogino et al., 2000).

When different nitrogen sources were used for lipase production by replacing both peptone and beef extract 
with tryptone (2\%), lipase titres further increased to 7.10 $\mathrm{IU} / \mathrm{mL}$ (Figure 2). Tryptone was reported for lipase production from Bacillus circulans MAS2 (Kademi et al., 2003) while yeast extract was used for Bacillus sp. (Thomas et al., 2003). Contrary to our results, a combination of tryptone (3.0\%) with yeast extract $(1.0 \%)$ was reported for lipase production from Ogino et al. (2000). Several researchers have reported the use of various carbon sources for influencing/increasing lipase production from both in bacteria and fungi (Pokorny et al., 1994; Mahadik et al., 2004). However, in this case, apart from glucose $(0.2 \%$ control), any other carbon source like fructose, maltose, mannitol and sucrose did not support good lipase production. A supportive role of glucose in lipase production was reported by Khyami-Horani (1996) and Kulkarni and Gadre, (2002) for $B$. licheniformis and $P$. fluorescens NS2W respectively.

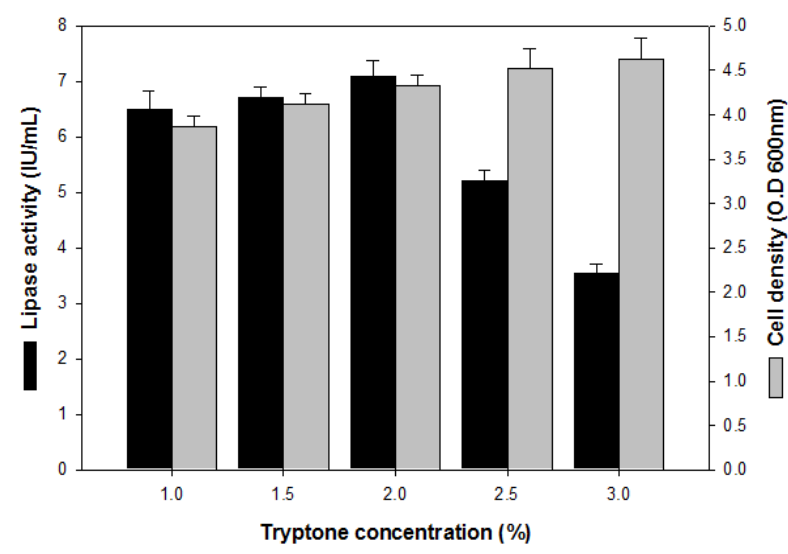

Figure 2: Effect of different concentrations of Tryptone (\%) on lipase production by Bacillus sp. RK- 3 in medium containing $1.5 \%$ sunflower oil $(\mathrm{v} / \mathrm{v})$ at $\mathrm{pH} 7.0,30^{\circ} \mathrm{C}$ and $250 \mathrm{rpm}$

Since the addition of surfactants improves the dispersion of oil in water, it also increases the permeation of lipase through cell membrane (Tan et al., 2004). Therefore, evaluation of different surfactants showed that Tween $80(0.02 \%)$ increased lipase titers to $8.10 \mathrm{IU} / \mathrm{mL}$ from this Bacillus sp. Sidhu et al. (1998) and Li et al. (2001) also reported Tween 80 for lipase production from Bacillus sp. RS-12 and Acinetobacter radioresistens. On the other hand, surfactants like Tween -20 and Tween -40 had an inhibitory effect on lipase production from Rhizopus oligosporus (Awan et al., 2003). Among different metal ions, $\mathrm{Ca}^{2+}(20 \mathrm{mM})$ increased lipase production to $9.12 \mathrm{IU} / \mathrm{mL}$. On the contrary, $\mathrm{Ca}^{2+}$ inhibited lipase production from Mucor hiemalis (Akhtar et al., 1980). Other metal ions reported for increasing lipase yield are $\mathrm{Mg}^{2+}$ for Bacillus subtilis 168 (Lin et al., 2006), Serratia marsescens mutant W1270 (Winkler and Stuckman, 1979) and Bacillus spp. RSJ1 (Sharma et al., 2002) and a combination of $\mathrm{Na}^{+}, \mathrm{K}^{+}$and $\mathrm{Ca}^{2+}$ for B. mycoides (Thomas et al., 2003).
When inoculum level was increased to $3.0 \%(\mathrm{v} / \mathrm{v})$ as against $2.0 \%(\mathrm{v} / \mathrm{v})$, final lipase yield of $10.56 \mathrm{IU} / \mathrm{mL}$ was obtained which is 3.2 fold higher as against the initial unoptimized yield $(3.28 \mathrm{lU} / \mathrm{mL})$. Any further increase in inoculum level lead to decreased lipase titers as higher inoculum concentrations may result in faster depletion of essential nutrients, thereby limiting further growth and reducing the lipase production.

\section{Scale up of lipase production}

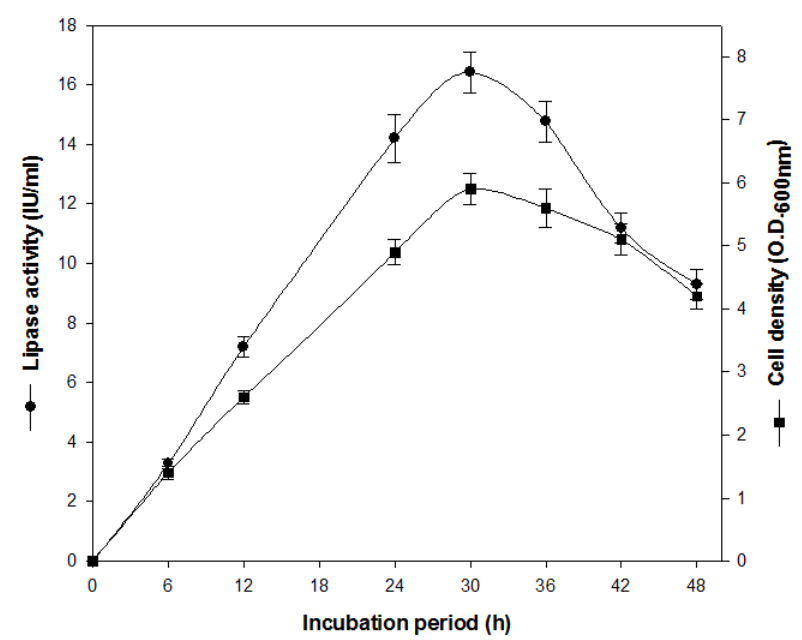

Figure 3: Scale up of lipase production in 10L fermentor

The enzyme production was carried out in a $10 \mathrm{~L}$ fermentor containing $7.5 \mathrm{~L}$ of the optimized production medium. The initial $\mathrm{pH}$ of the medium was kept at 7.0 and was only monitored. The fermentation was initiated with airflow of $5 \mathrm{lpm}, 30^{\circ} \mathrm{C}$ and initial agitation rate of $250 \mathrm{rpm}$. The dissolved oxygen was maintained at $20-40 \%$ constant saturation level. Use of these conditions for production resulted in final enhancement of lipase titers to $16.4 \mathrm{IU} / \mathrm{mL}$ in $30 \mathrm{~h}$ (Figure 3 ). This could be attributed to a better controlled environment in fermentor than in the flask. After $30 \mathrm{~h}$, the substrate in the growth medium became a limiting factor, which resulted in no further growth and lipase production. The scale up finally resulted in an overall 6.0 fold increase in enzyme titers as against initial unoptimized production $(3.28 \mathrm{IU} / \mathrm{mL})$. The productivity also increased to $0.547 \mathrm{IU} / \mathrm{mL} / \mathrm{h}$ as against initial unoptimized $(0.091 \mathrm{lU} / \mathrm{mL} / \mathrm{h})$. Similarly, an increase in lipase titers was observed due to availability of nutrients, better agitation and aeration conditions by Rathi et al. (2002) for B. cepacia. However, in presence of higher dissolved oxygen concentrations, higher production titers were attained when Thermos thermophilus was grown in fermentor (Dominguez et al., 2005).

The lipase was partially purified by ammonium sulphate precipitation and lyophilized with final yield of 1.2 $\mathrm{IU} / \mathrm{mg}$ and a fold purification of 4.46 . 


\section{Organic solvent stability}

Since, synthesis of CBS is carried out in presence of organic solvents, primarily hexane, the stability of this lipase was evaluated in different solvents. After $24 \mathrm{~h}$ of incubation, this lipase exhibited $95.12 \%$ stability in hexane (Figure 4), followed by THF (75.83\%) and petroleum ether (73.85\%). Similarly, Lin et al. (2006) reported $100 \%$ residual activity in hexane by Neurospora crassa lipase. Contrary to our results, Sugihara et al. (1991) reported inhibitory effect of hexane on Bacillus sp. lipase. On the other hand, minimum stability with a loss of nearly $89 \%$ was observed with propanol. However, more than $90 \%$ lipase activity was reported from B. cepacia after $48 \mathrm{~h}$ of incubation in propanol (Yang et al., 2007).

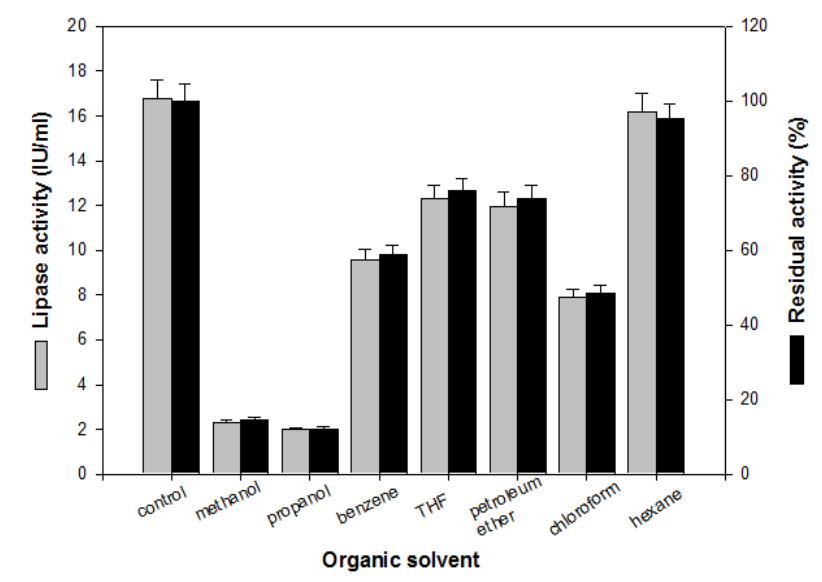

Figure 4: Effect of organic solvent on lipase production

\section{Synthesis of cocoa butter substitute}

Palm oil when transesterified by this Bacillus RK-3 lipase in presence of methyl stearate and hexane produces a thick, viscous and cream colored product. On qualitatively evaluating this product on TLC (Figure 5) using a solvent system of hexane: diethyl ether $(4: 1)$, showed that the TAG distribution in cocoa butter substitute obtained through Bacillus sp. RK-3 is similar to that of standard cocoa butter. These three compounds are also a major component of Cocoa Butter. Further quantification of the product by GC analysis (Figure 6) showed the presence of three types of triacylglycerols (TAGs) i.e. 1(3) palmitoyl-2oleolyl-3(1) stearyl-sn-glycerol (POS), 1(3) stearoyl-2oleoyl-3(1) stearoyl-sn-glycerl (SOS) and 1(3) palmitoyl-2oleoyl-3(1) palmitoyl-s-glycerol (POP) which resulted in $38.28 \%$ synthesis of POS, $25.13 \%$ of SOS and $19.76 \%$ of POP indicating a Cocoa Butter Substitute synthesis efficiency of $83.17 \%$.

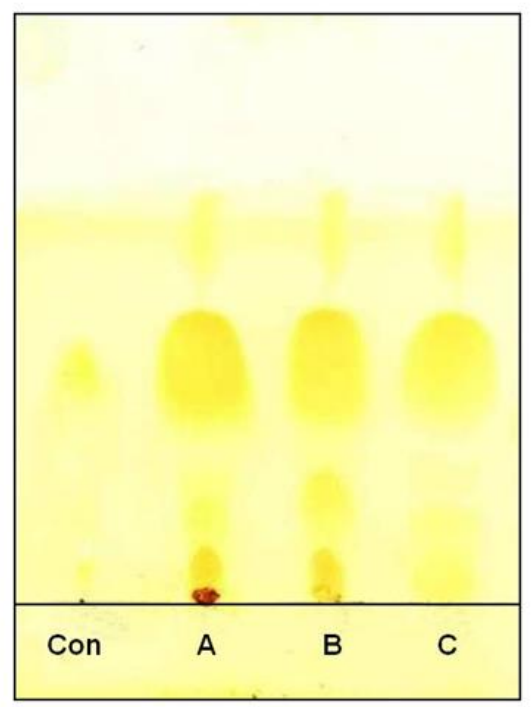
Con : Control (without lipase)
A : Reaction product (with Bacillus sp. RK-3)
B : Reaction product (with Rhizomucormeihei lipase, commercial lipase)
C : Commercial Cocoa butter(standard)

Figure 5: Thin Layer Chromatography of the Cocoa Butter Substitute synthesized through transesterification of palm oil and methyl stearate in presence of Bacillus sp. RK-3 lipase in hexane

This distribution of the TAG components is similar to that of pure $C B$ and results indicate that the product formed is a CBS. The CBS formed by transesterification of palm oil by this lipase solidified at room temperature with a sharp melting point of $33{ }^{\circ} \mathrm{C}$. Pure $\mathrm{CB}$ also melts between 32 to $35^{\circ} \mathrm{C}$ (Liu et al., 2007) indicating similarity with the product formed by this lipase.

Furthermore, the CBS formed was reconfirmed by NMR (Figure 7). The results of the structural analysis of CBS carried out by ${ }^{1} \mathrm{H}$ NMR $\left(\mathrm{CDCl}_{3}, 300 \mathrm{MHz}\right)$ are $\delta 0.85$ $0.90\left(9 \mathrm{H}, \mathrm{t}, \mathrm{CH}_{3}\right.$ palmitic $\mathrm{C}-16$ and stearate ester $\left.\mathrm{C}-18\right)$, $1.25\left(48 \mathrm{H}\right.$, brs, $12 \times\left(\mathrm{CH}_{2}\right)_{2}$ at $\mathrm{C}-4$ to 15 attached palmitic \& $28 \mathrm{H}$, brs, $14 \mathrm{x} \mathrm{CH}_{2}$ stearate ester) $1.61\left(6 \mathrm{H}, \mathrm{m}, \mathrm{CH}_{2}\right.$ palmitic \& stearate ester $\mathrm{C}-3), 2.30(6 \mathrm{H}, \mathrm{t}, J=6.0 \mathrm{~Hz}$, $\mathrm{CH}_{2}, \mathrm{C}-2$, palmitic and stearate ester linkage), 4.26-4.32 $\left(4 \mathrm{H}, \mathrm{m}, \mathrm{CH}_{2} \mathrm{O}\right.$ palmitic ester), $5.34(1 \mathrm{H}, \mathrm{m}, \mathrm{CHO}$ stearate ester).

Synthesis of CBS using palm oil has been reported by Bloomer et al. (1990), Undurraga et al. (2001), Abigor et al. (2006) and Pinyaphong and Phutrakul (2009). Palm oil is often a preferred source as it is a low cost fat and is readily available. Another reason is that the main component of palm oil mid fraction is the triglyceride POP which can be readily converted by transesterification reaction to POS and SOS, the major components in Cocoa Butter (Bloomer et al., 1990). 


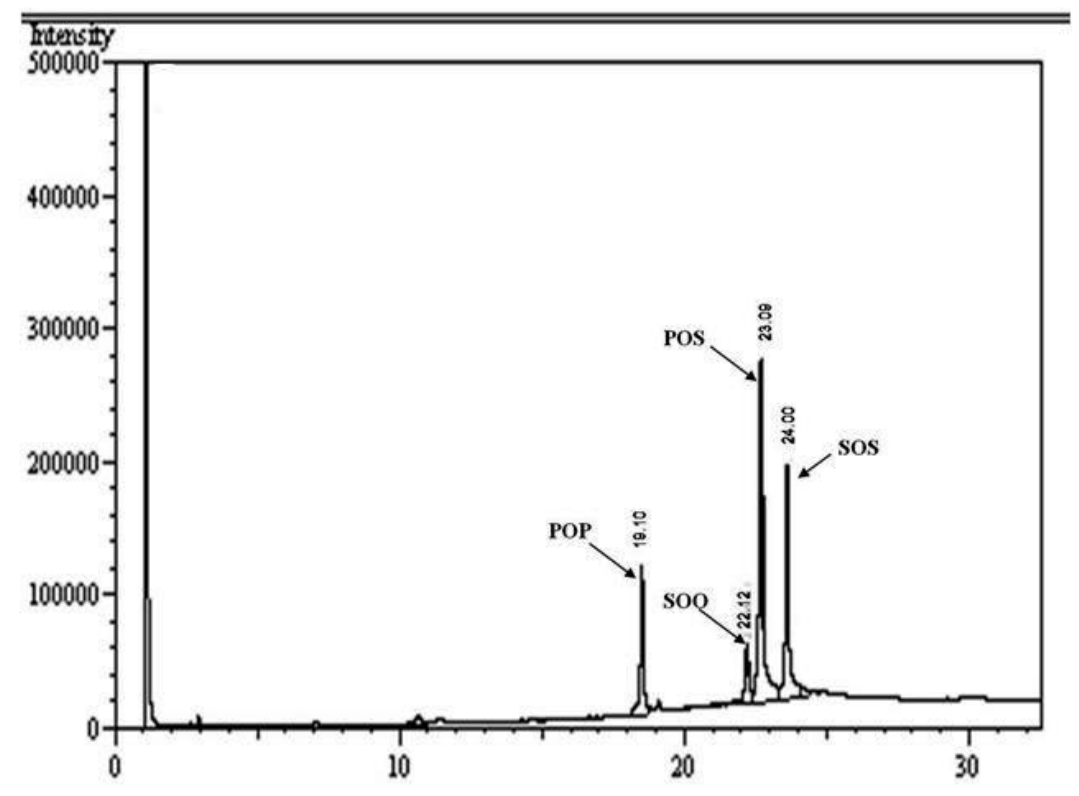

Figure 6: Gas Chromatography of CBS synthesized through transesterification of palm oil and methyl stearate in presence of Bacillus sp. RK-3 lipase in hexane. Rt. 19.10- POP; 22.12- SOO; 23.09- POS; 24.00- SOS

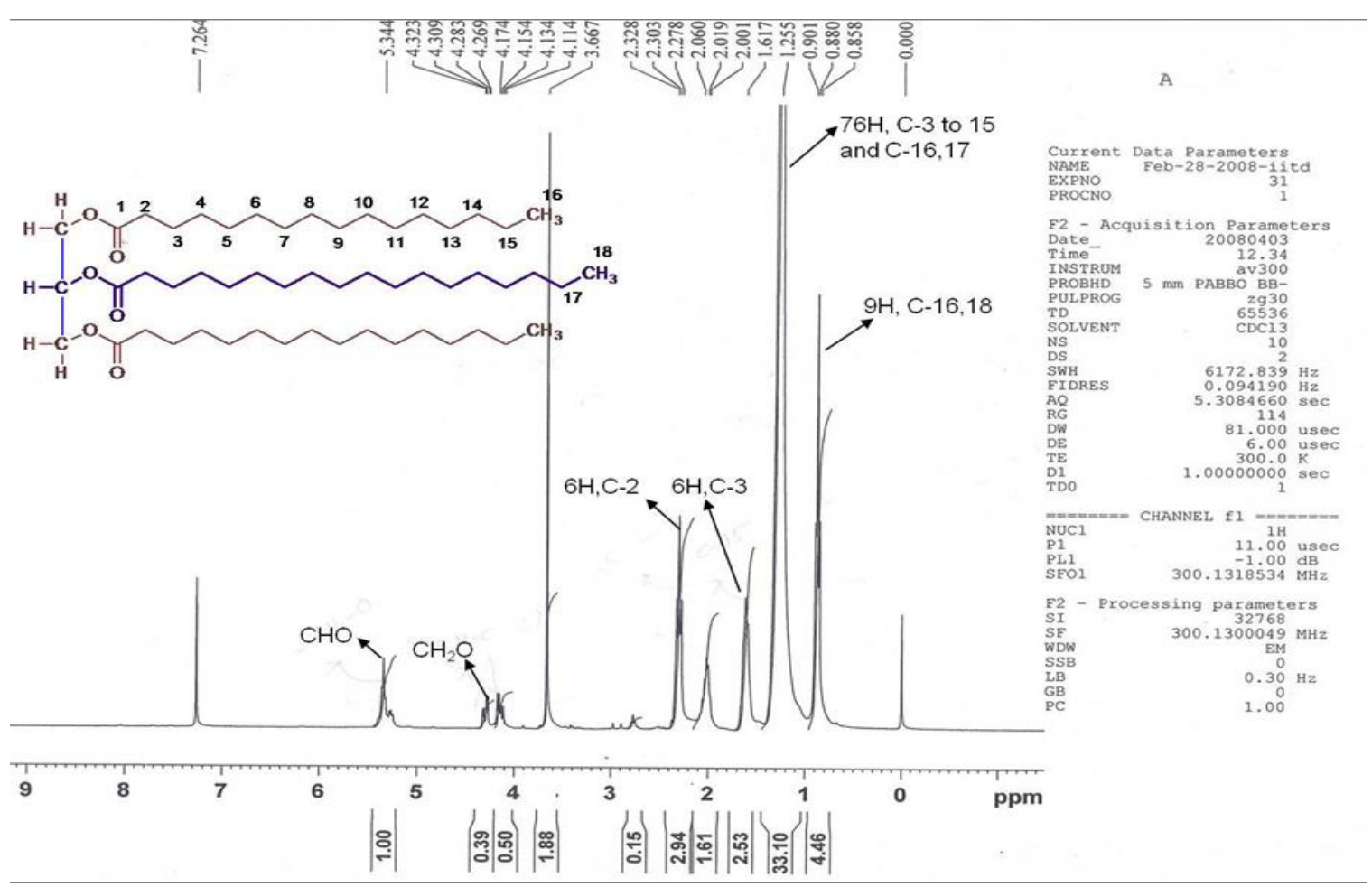

Figure 7: NMR of the CBS synthesized through transesterification of palm oil and methyl stearate in presence of Bacillus sp. RK-3 lipase in hexane 
The important outcome from this study is that till date all the cocoa butter substitute synthesis has been carried out by Lipozymes, Amano, C. papaya lipase (Abigor et al., 2003; Liu et al., 2007; Pinyaphong and Phutrakul, 2009) However, on commercial scale it is worthwhile to have an enzyme supply which is not limiting. Bacillus sp. RK-3 is important since it produces indigenous lipase.

\section{CONCLUSION}

This Bacillus sp. RK-3 produces a 1, 3 regiospecific lipase. This lipase could efficiently carry out synthesis of CBS from palm oil and methyl stearate in presence of hexane. Since, this lipase holds commercial importance, its production was process optimized initially in flasks resulting in $10.56 \mathrm{IU} / \mathrm{mL}$. Further scale up to $10 \mathrm{~L}$ bioreactor resulted in $16.41 \mathrm{IU} / \mathrm{mL}$ of lipase titres in $30 \mathrm{~h}$. The CBS synthesized had similar properties to that of commercially available cocoa butter.

\section{REFERENCES}

Abigor, R. D., Marmer, W. N., Foglia, T. A., Jones, K. C., Diciccio, R. J., Ashby, R. and Uadia, P. O. (2003). Production of cocoa butter-like fats by the lipase-catalyzed interesterification of palm oil and hydrogenated soybean oil. Journal of the American Oil Chemists Society 80, 1193-1196.

Abramic, M., Lescic, I., Korica, T., Vitale, L., Saenger, W. and Pigac, J. (1999). Purification and properties of extracellular lipase from Streptomyces rimosus. Enzyme and Microbial Technology 25, 522-529.

Adlercreutz, P. (1994). Enzyme-catalyzed lipid modification. Biotechnology and Genetic Engineering Reviews 12, 231-254.

Akhtar, M. W., Mirza, A. Q. and Chughtai, M. I. D. (1980) Lipase Induction in Mucor hiemalis. Applied and Environmental Microbiology 40(2), 257-263.

Awan, U. F., Shafiq, K., Mirza, S., Ali, S., Rahman, A. U. and Haq, I. U. (2003). Mineral constituents of culture medium for lipase production by Rhizopus oligosporous fermentation. Asian Journal of Plant Sciences 2(12), 913-915.

Bloomer, S., Adlercreutz, P. and Mattiasson, B. (1990). Triglyceride interesterification by lipases. I. Cocoa butter equivalents from Fraction Palm Olein (FPO). Journal of the American Oil Chemists Society 67, 519-524.

Dominguez, A., Pastrana, L., Longo, M. A., Rua, M. L. and Sanroman, M. A. (2005). Lipolytic enzyme production by Thermus thermophilus HB27 in a stirred tank bioreactor. Biochemical Engineering Journal 26, 95-99.

Gao, X. G., Cao, S. G. and Zhang, K. C. (2000). Production, properties and application to nonaqueous enzymatic catalysis of lipase from a newly isolated Pseudomonas strain. Enzyme and Microbial Technology 27, 74-82.

Gupta, N., Sahai, V. and Gupta, R. (2007). Alkaline lipase from a novel strain Burkholderia multivorans:
Statistical medium optimization and production in a bioreactor. Process Biochemistry 42, 518-526.

Hasan, F., Shah, A. A. and Hameed, A. (2006). Industrial applications of microbial lipases. Enzyme and Microbial Technology 39, 235-251.

Jaeger, K. E., Dijkstra, B. W. and Reetz, M. T. (1999). Bacterial biocatalysts: molecular biology, three dimensional structures and biotechnological application of lipases. Annual Reviews of Microbiology 53, 315-351.

Kademi, A., Lee, B. and Houde, A. (2003). Production of heterologous microbial lipases by yeasts. Indian Journal of Biotechnology 2, 346-355.

Khyami-Horani, H. (1996). Thermo tolerant strains of Bacillus licheniformis producing lipase. World Journal of Microbiology and Biotechnology 12, 399-401.

Kulkarni, N. and Gadre, R. V. (2002). Production and properties of an alkaline, thermophilic lipase from Pseudomonas fluorescens NS2W. Journal of Industrial and Food Microbiology 28, 344-348.

Lawrence, R. C., Fryer, T. F. and Reiter, B. (1967). Rapid method for the quantitative estimation of microbial lipases. Nature 213, 1264-1265.

Li, C. Y., Cheng, C. Y. and Chen, T. L. (2001). Production of Acenetobacter radioresistens lipase using Tween 80 as the carbon source. Enzyme and Microbial Technology 29, 258-263.

Lin, T. J., Chen, S. W. and Chang, A. C. (2006). Enrichment of $n-3$ PUFA contents on triglycerides of fish oil by lipase-catalyzed trans-esterification under supercritical conditions. Biochemical Engineering Journal 29, 27-34.

Lipp, M. and Anklam, E. (1998). Review of cocoa butter and alternative fats for use in chocolate-Part A. Compositional data. Food Chemistry 62, 73-97.

Litthauer, D., Ginster, A. and van Eeden Skein, E. (2002). Pseudomonas luteola lipase: A new member of the 320-residue Pseudomonas lipase family. Enzyme and Microbial Technology 30(2), 209-215.

Liu, K. J., Cheng, H. M., Chang, R. C. and Liu, K-M. (2007). Enzymatic synthesis of cocoa butter analog through Interesterification of lard and tristearin in supercritical carbon dioxide by lipase. Food chemistry 100, 1303-1311.

Macrae, A. R. and Hammond, R. C. (1985). Present and future applications of lipases. Biotechnology \& Genetic Engineering Reviews 3, 193-217.

Mahadik, N. D., Bastawde, K. B., Puntambekar, U. S., Khire, J. M. and Gokhale, D. V. (2004). Production of acidic lipase by a mutant of Aspergillus niger NCIM 1207 in submerged fermentation. Process Biochemistry 39, 2031-2034.

Ogino, H., Nakagawa, S., Shinya, K., Muto, T., Fujimura, N., Yasuda, M. and Ishikawa, H. (2000). Purification and characterization of organic solventstable lipase from organic solvent tolerant Pseudomonas aeruginosa LST-03. Journal of Bioscience and Bioengineering 5, 451-457.

Pinyaphong, P. and Phutrakul, S. (2009). Synthesis of cocoa butter equivalent from palm oil by Carica 
papaya lipase-catalyzed interesterification. Chiang Mai Journal of Science 36(3), 359-368.

Pokorny, D., Friedrich, J. and Cimerman, A. (1994). Effect of nutritional factors on lipase biosynthesis by Aspergillus niger. Biotechnology Letters 16, 363-366.

Rathi, P., Goswami, V. K., Sahai, V. and Gupta, R. (2002). Statistical medium optimization and production of a hyperthermostable lipase from Burkholderia cepacia in a bioreactor. Journal of Applied Microbiology 93, 930-936.

Saxena, R. K., Ghosh, P. K., Gupta, R., Davidson, W. S., Bradoo, S. and Gulati, R. (1999). Microbial lipases: potential biocatalyst for the future industry. Current Science 77101-77115.

Sharma, R., Soni, S. K., Vohra, R. M., Gupta, L. K. and Gupta, J. K. (2002). Production of extracellular alkaline lipase from a Bacillus sp. RSJ1 and its application in ester hydrolysis. Indian Journal of Microbiology 42, 49-54.

Sharma, R., Chisti, Y. and Banerjee, U. C. (2001). Production, purification, characterization and applications of lipases. Biotechnol Advances 19, 627 662.

Shukla, V. K. S. (1996). Confectionery fats. In: Developments in oils and fats. Hamilton, R. J. (ed.). Blackie Academic and Professional, Glasgow. pp. 6694.

Sidhu, P., Sharma, R., Soni, S. K. and Gupta, J. K. (1998). Effect of cultural conditions on extracellular alkaline lipase production from Bacillus sp. RS-12 and its characterization. Indian Journal of Microbiology 38, 9-14.

Smith, K. W. (2001). Cocoa butter and cocoa butter equivalents. In: Structured and Modified Lipids. Gunstone, F. D. (ed.). Marcel Dekker, Inc., New York. pp. 401-422.

Sugihara, A., Tani, T. and Tominaga, Y. (1991). Purification and characterization of a novel thermostable lipase from Bacillus sp. Journal of Biochemistry 109, 211-216.

Tan, T., Zhang, M., Xu, J. and Zhang, J. (2004). Optimization of culture conditions and properties of lipase from Penicillium camembertii Thom PG-3. Process Biochemistry 39, 1495-1502.

Tchobo, F. P., Piombo, G., Pina, M., Soumanou, M. M., Villeneuve, P. and Sohounhloue, D. C. K. (2009). Enzymatic synthesis of cocoa butter equivalent through transesterification of Penadesma $B_{\cup}$ tyracea butter. Journal of Food Lipids 16, 605-617.

Thomas, A., Mathew, M., Valsa, A. K., Mohan, S. and Manjula, R. (2003). Optimaisation of growth condition for the production of extracellular lipase by Bacillus mycoides. Indian Journal of Microbiology 43(1), 6769.

Undurraga, D., Markovits, A. and Erazo, S. (2001). Cocoa butter equivalent through enzymic interesterification of palm oil midfraction. Process Biochemistry 36, 933-939.

Wang, H-X., Wu, H., Ho, C-T. and Weng, X-C. (2006). Cocoa butter equivalent from enzymatic interesterification of tea seed oil and fatty acid methyl esters. Food Chemistry 97661-97665.

Winkler, U. K. and Stuckman, M. (1979). Glycogen, hyaluronate, and some other polysaccharides greatly enhance the formation of exolipase by Serratia marcescens. Journal of Bacteriology 138, 663-679.

Yang, J., Guo, D. and Yan, Y. (2007). Cloning, expression and characterization of a novel thermal stable and short-chain alcohol tolerant lipase from Burkholderia cepacia strain G63. Journal of Molecular Catalysis B: Enzymatic 45, 91-96. 